\title{
Construção e aplicação de matrizes bibliométrica e epistemológica para análise do referencial freireano no Ensino de Ciências
}

Gabriela Zauith

Doutora em Educação pela UFSCar

Maria Cristina Piumbato Innocentini Hayashi

Professora Associada da UFSCar

\section{Resumo}

O artigo apresenta os resultados de uma pesquisa que investigou a apropriação do referencial teórico de Paulo Freire em teses e dissertações nas áreas de Ensino de Ciências e Educação CTS (Ciência, Tecnologia e Sociedade). Através de uma análise bibliométrica e epistemológica de quatro matrizes que agregam os níveis epistemológico, ontológico e gnosiológico foi identificada a presença do referencial teórico de Paulo Freire nesses trabalhos.

Palavras-Chave: Ensino de Ciências; Educação CTS; Análise bibliométrica; Análise epistemológica; Paulo Freire.

\begin{abstract}
The article presents the results of a survey that investigated the appropriation of the theoretical framework of Paulo Freire in theses and dissertations in the areas of Teaching Science Education and STS (Science, Technology and Society). Through a bibliometric analysis and epistemological four matrices that add the epistemological, ontological and gnosiologic levels were identified under the theoretical framework of Paulo Freire in these works.
\end{abstract}

Key-Words: Science Teaching; STS Education; Bibliometric analysis; Epistemological analysis Paulo Freire. 
1. Introdução

S estudos de Sánchez Gamboa (2012) analisaram as opções epis-
temológicas no campo da Educação no período entre 1971 a
1984 , e os resultados obtidos apontam que apesar de inicialmente predominarem as abordagens empírico-analíticas e posteriormente as abordagens fenomenológico-hermêuticas essas diminuem gradualmente devido ao crescimento das critico-dialéticas, que com referências do materialismo histórico passam a ser utilizadas na prática educacional para explicar as relações e conflitos com a sociedade capitalista.

O Ensino de Ciências, assim como o campo da Educação, busca por paradigmas que superem abordagens técnico-lineares e positivistas da produção do conhecimento. A pedagogia de Paulo Freire apropriada pelo Ensino de Ciências e pela Educação CTS supera esse paradigma em busca de uma proposta dialógica.

Ao lado de Dermeval Saviani e José Carlos Libâneo Paulo Freire é um dos poucos educadores citados em pesquisas do Ensino de Ciências, conforme constatou Lemgruber $(1999,2000)$ ao pesquisar um corpus de 288 teses e dissertações sobre o ensino médio e fundamental de Ciências Físicas e Biológicas defendidas no Brasil, de 1981 a 1995. Naquela ocasião o autor já salientava a necessidade de se superar o afastamento entre os campos da Educação em Ciência e o pensamento pedagógico, ao constatar nesses trabalhos a ausência de pesquisadores brasileiros que fizeram a história do Ensino de Ciências, como Fernando de Azevedo, Oswaldo Frota-Pessoa, Isaías Raw e Newton Santos.

A pedagogia freireana está contextualizada na realidade concreta que vivia, seja na pobreza do Jaboatão, em suas aulas pela Europa e Estados Unidos, ou como secretário de Educação em São Paulo. A leitura de sua obra revela, entretanto, que Freire não faz referência direta ao Ensino de Ciências e tampouco cita a perspectiva Ciência, Tecnologia e Sociedade (CTS).

A possibilidade de utilizar a pedagogia dialógica de Paulo Freire no Ensino de Ciências, particularmente no ensino de Física, surgiu entre um 
grupo de estudiosos de Freire constituído em meados da década de 1970 sob a liderança de Luis Carlos de Menezes, do Instituto de Física da USP, e formado por José Peres Angotti, Maria Cristina Dal Pian, Demétrio Delizoicov, Marta Pernambuco e João Zanetic. Tendo como traço marcante do grupo a dialética, o encontro com a pedagogia de Paulo Freire propiciou as pistas para o empreendimento de projetos de ensino e de formação de professores de Ciências e de Física que tem na dialogicidade uma característica visceralmente problematizadora do conhecimento prévio do estudante.

A pedagogia de Freire contempla a concepção epistemológica, principalmente quando são consideradas duas categorias de conhecimento: o científico e o do senso comum. A abordagem baseada somente nos conceitos científicos, não considerando o conhecimento prévio do aluno, subestima sua capacidade e suas vivências. Nessa visão epistemológica, o sujeito é visto como ontológico capaz de se constituir "com um aparato cognitivo que lhe permita conhecer, caracterizando-se como um sujeito epistêmico" (DELIZOICOV, ANGOTTI, PERNAMBUCO, 2011, p.184b).

A problemática da extensão como transmissão de conhecimento imposto aos trabalhadores rurais sem levar em consideração seu conhecimento empírico, baseado no conhecimento mágico, em suas tradições e heranças culturais é tratada por Freire, que contesta essa imposição realizada por meio da invasão cultural favorecendo a comunicação partindo da educação dialógica (FREIRE, 1983a).

Esse artigo apresenta os resultados de uma pesquisa que investigou a apropriação do referencial teórico de Paulo Freire em teses e dissertações nas áreas de Ensino de Ciências e Educação CTS (Ciência, Tecnologia e Sociedade). Através de uma análise bibliométrica e epistemológica de quatro matrizes que agregam os níveis epistemológico, ontológico e gnosiológico foi identificada a presença do referencial teórico de Paulo Freire nesses trabalhos.

\section{Delineamento metodológico}

O delineamento metodológico adotado para a construção dessas matrizes 
pode ser caracterizado como uma pesquisa do tipo qualitativa em relação à abordagem do problema e bibliográfica e documental em relação aos procedimentos técnicos utilizados, uma vez que estabelece relações entre os dados coletados e a literatura existente objetivando refletir sobre a problemática pesquisada.

O objeto de análise foi constituído por 13 trabalhos - quatro teses de doutorado e nove dissertações de mestrado que foram selecionados entre as 43 teses e dissertações coletadas no Banco de Teses da Capes e no BDTD. O critério adotado para composição dessa amostra foi a Apropriação de Modo de Trabalho (CATANI; CATANI; PEREIRA, 2001) o que possibilitou a seleção dos trabalhos mais representativos que explicitassem claramente no referencial teórico a interface da abordagem freireana com a Educação CTS ou Ensino de Ciências, evidenciando maneiras de apropriação reveladoras da utilização sistemática de noções e conceitos de Paulo Freire.

Os procedimentos metodológicos utilizados seguiram aqueles utilizados em pesquisas anteriores das autoras (HAYASHI et al, 2008; ZAUITH, OGATA, HAYASHI, 2010; 2011; SILVA, HAYASHI, HAYASHI, 2011; ZAUITH, HAYASHI, 2011a; 2011b, 2013) e abrangeram as abordagens bibliométrica e epistemológica com a construção de quatro matrizes de análises: a) matriz bibliométrica do referencial freireano; b) matriz de apropriação teórica do referencial freireano; c) matriz paradigmática CTS e d) matriz de análise epistemológica do referencial freireano. No Quadro 1 apresentamos uma síntese dessas quatro matrizes de análise e com mais profundidade apresentamos uma discussão sobre os resultados da aplicação da matriz epistemológica do referencial freireano nos 13 trabalhos selecionados.

Quadro 1 - Síntese das etapas de construção das Matrizes de Análise

\begin{tabular}{|l|l|}
\hline \multicolumn{2}{|l|}{ Matriz bibliométrica do Referencial Freireano } \\
\hline Etapa teórica & $\begin{array}{l}\text { Leitura dos artigos Hayashi et al. (2008); Zauith, Ogata e Hayashi } \\
(2010 ; 2011) ; \text { Silva, Hayashi E Hayashi (2011); Zauith e Hayashi } \\
(2011 \mathrm{a} ; 2011 \mathrm{~b}, 2013) .\end{array}$ \\
\hline $\begin{array}{l}\text { Etapa } \\
\text { metodológica }\end{array}$ & $\begin{array}{l}\text { 1. Coleta de teses e dissertações no Bando de Teses da CAPES e dos } \\
\text { Cadernos de Indicadores de Disciplinas da CAPES. 2. Definição dos } \\
\text { Parâmetros: Autoria (Autores e orientadores), Temporalidade (Ano de } \\
\text { defesa), Graus de titulação acadêmica (Mestrado, Doutorado e } \\
\text { Mestrado Profissionalizante), Vinculação institucional (Programas de } \\
\text { Pós-Graduação e Instituições de Ensino Superior), Nível de } \\
\text { hierarquização do conhecimento (Grandes Áreas de conhecimento), }\end{array}$ \\
\hline
\end{tabular}




\begin{tabular}{|c|c|}
\hline & $\begin{array}{l}\text { Temáticas (Temas abordados) e Disciplinas de pós-graduação com } \\
\text { coleta de dados das ementas, títulos e referências das disciplinas } \\
\text { (Enfoque freireano na abordagem CTS). }\end{array}$ \\
\hline \multicolumn{2}{|r|}{ Matriz de Apropriação Teórica do Referencial Freireano } \\
\hline Etapa teórica & $\begin{array}{l}\text { Leitura integral das obras de Paulo Freire }(1959,1963,1978,1979 a \text {, } \\
\text { 1979b, 1983a, 1983b, 1987, 1991, 1992, 1993, 1994, 1997, 2000, 2001, } \\
\text { 2006, 2007, 2011) e de seus coautores, colaboradores e outros autores } \\
\text { que refletiram sobre sua obra. }\end{array}$ \\
\hline $\begin{array}{l}\text { Etapa } \\
\text { metodológica }\end{array}$ & $\begin{array}{l}\text { 1. Definição do tipo de apropriação: a) "apropriação incidental", } \\
\text { caracterizada por referências rápidas a Paulo Freire e suas obras; b) } \\
\text { "apropriação conceitual tópica", na qual deixar entrever a utilização, } \\
\text { conquanto não sistemática, de citações e eventualmente de conceitos de } \\
\text { Paulo Freire; e c) "apropriação do modo de trabalho", constituindo-se } \\
\text { em maneiras de apropriação reveladoras da utilização sistemática de } \\
\text { noções e conceitos de Paulo Freire. 2. Construção de indicadores de: } \\
\text { Referências que embasaram o referencial teórico do trabalho; Tipo de } \\
\text { publicação; Número de vezes que a obra é citada. }\end{array}$ \\
\hline \multicolumn{2}{|r|}{ Matriz Paradigmática CTS } \\
\hline Etapa teórica & $\begin{array}{l}\text { Leitura integral das obras de Ziman }(1980 ; 1994) \text { e Aikenhead, (2000, } \\
2003) \text { autores emblemáticos no campo CTS e Educação CTS, e dos } \\
\text { textos de Lemgruber }(1999,2000) \text { e Krasilshick (2000) que enfocam o } \\
\text { Ensino de Ciências sob a perspectiva CTS. }\end{array}$ \\
\hline $\begin{array}{l}\text { Etapa } \\
\text { metodológica }\end{array}$ & $\begin{array}{l}\text { 1. Identificação dos níveis teórico (concepções de Ciência, Tecnologia e } \\
\text { Sociedade) e epistemológico (concepçôes de CTS, Educação CTS, } \\
\text { Ensino CTS, Ensino de Ciências). 2. Estabelecimento das categorias de } \\
\text { análise de cada nível }\end{array}$ \\
\hline \multicolumn{2}{|r|}{ Matriz de Análise Epistemológica do Referencial Freireano } \\
\hline Etapa teórica & $\begin{array}{l}\text { Leitura integral de obras de Paulo Freire }(1959,1963,1978,1979 \text { a, } \\
\text { 1979b, 1983a, 1983b, 1987, 1991, 1992, 1993, 1994, 1997, 2000, 2001, } \\
\text { 2006, 2007, 2011) e de outros autores que refletiram sobre sua obra e } \\
\text { trajetória }\end{array}$ \\
\hline $\begin{array}{l}\text { Etapa } \\
\text { metodológica }\end{array}$ & $\begin{array}{l}\text { 1. Identificação de conceitos freireanos ("saber de experiência feito", } \\
\text { "extensão/comunicação", } \\
\text { "rigor/rigorosidade metódica", "sujeito/objeto") que permitiram } \\
\text { identificar os pressupostos epistemológicos de seu pensamento. } 2 . \\
\text { Estabelecimento do núcleo referencial freireano (nível, objetivo e } \\
\text { referencial de análise). } 3 . \text { Delineamento dos pressupostos } \\
\text { epistemológico, gnosiológico e epistemológico do pensamento } \\
\text { freireano. 4. Identificação das concepções de ciência, sujeito-objeto, } \\
\text { homem, realidade e educação em Paulo Freire. 5. Determinação das } \\
\text { categorias de análise do referencial de análise freireano. }\end{array}$ \\
\hline
\end{tabular}

Elaboração própria

\section{Matriz bibliométrica}

Adotou-se a abordagem bibliométrica para a análise dos dados e para isso foi construída uma matriz bibliométrica tendo como referência trabalhos anteriores (HAYASHI et al., 2008; ZAUITH, OGATA e HAYASHI, 2010; 2011; SILVA, HAYASHI e HAYASHI, 2011; ZAUITH e HAYASHI, 2011a; 2011b, 2013). Os dados foram coletados das teses e dissertações e dos Cadernos de Indicadores de Disciplinas da CAPES. Complementarmente 
também foram compulsados os Cadernos de Indicadores da CAPES que contêm dados oficiais gerados pelos Programas de Pós-Graduação do país e posteriormente são consolidados no sistema de informação Coleta Capes e passam a integrar o Sistema de Avaliação da Pós-Graduação. Após a validação nas avaliações anuais e trienais realizadas pela CAPES, tais indicadores subsidiam os Programas e a agência de fomento na elaboração de diagnósticos, planejamento de ações a serem alcançadas e avaliações de desempenho.

Os Cadernos de Indicadores da CAPES são integrados por um conjunto de documentos que abrangem a produção técnica; teses e dissertações; produção bibliográfica; disciplinas; produção artística; corpo docente, vínculo formação; proposta do programa; linhas de pesquisa; projetos de pesquisa; produção e atuação docente.

Nessa pesquisa foram selecionados os Cadernos de Indicadores das Disciplinas ministradas nos Programas de Pós-Graduação pertencentes à área "Ensino" - que está inserida na grande área de avaliação Multidisciplinar - e os dados são referentes ao triênio de avaliação 20072009. O Caderno de Indicadores das Disciplinas contém as seguintes informações: título da disciplina, total de créditos, docente responsável, ementa, e bibliografia. A coleta visou identificar as disciplinas que utilizaram o referencial teórico freireano, e como recurso de busca foi utilizado o prefixo "freir" nos títulos, ementas e bibliografias indicadas, o que resultou em 57 disciplinas distribuídas entre 22 instituições. Entretanto, foi realizado um recorte na totalidade dos dados coletados, por meio da seleção dos dados da UFSC, UnB e USP. A escolha dessas instituições devese ao fato de que são as que mais concentram trabalhos com o enfoque freireano.

Assim, com base nessas variáveis foi construída a matriz bibliométrica que leva em conta os parâmetros e os respectivos indicadores bibliométricos, conforme explicitado no Quadro 2

Quadro 2 - Matriz Bibliométrica 


\begin{tabular}{|l|l|}
\hline Autoria & Autores e orientadores \\
\hline Temporalidade & Ano de defesa \\
\hline Graus de titulação acadêmica & $\begin{array}{l}\text { Mestrado, Doutorado e Mestrado } \\
\text { Profissionalizante }\end{array}$ \\
\hline Vinculação institucional & $\begin{array}{l}\text { Programas de Pós-Graduação e } \\
\text { Instituições de Ensino Superior }\end{array}$ \\
\hline $\begin{array}{l}\text { Nível de hierarquização do } \\
\text { conhecimento }\end{array}$ & Grandes Áreas de conhecimento \\
\hline Temáticas pós-graduação & Temas abordados \\
\hline $\begin{array}{l}\text { Disciplinas de } \\
\text { (ementas, títulos e referências das } \\
\text { disciplinas) }\end{array}$ & Enfoque freireano na abordagem CTS \\
\hline
\end{tabular}

Elaboração própria

\section{Matriz de apropriação teórica do referencial freireano}

A etapa teórica de construção dessa matriz exigiu a leitura integral de obras de Paulo Freire (1959, 1963, 1978, 1979a, 1979b, 1983a, 1983b, 1987, 1991, 1992, 1993, 1994, 1997, 2000, 2001, 2006, 2007, 2011) de coautores e colaboradores de Paulo Freire e de outros autores que refletiram sobre sua obra.

O objetivo da aplicação da matriz de análise da apropriação teórica do referencial freireano é investigar a apropriação do referencial teórico-metodológico de Paulo Freire, por meio de quatro indicadores que visam identificar as referências das obras de Paulo Freire e os tipos de apropriação realizada pelos autores dos trabalhos analisados.

Para identificar quais e como são citadas as obras desse autor nos trabalhos analisados foram construídos os seguintes indicadores: a) Referências que embasaram o referencial teórico do trabalho; b) Tipo da publicação; c) Número de vezes que obra é citada; d) A utilização da referência é utilizada na metodologia, para interpretação dos dados ou na conclusão?

Para verificar as referências que embasam o referencial teórico do trabalho foram utilizados os três tipos de apropriação do referencial teórico freireano já utilizados em pesquisas anteriores sobre análise da produção científica em Ensino e Educação CTS (ZAUITH; HAYASHI, 2011b) e baseados naqueles propostos por Catani, Catani e Pereira (2001), a saber:

a) "apropriação incidental” (AI), caracterizada por referências rápidas a Paulo Freire e suas obras;

b) “apropriação conceitual tópica” (ACT), na qual deixar entrever a 
utilização, conquanto não sistemática, de citações e eventualmente de conceitos de Paulo Freire; e

c) "apropriação do modo de trabalho" (AMT), constituindo-se em maneiras de apropriação reveladoras da utilização sistemática de noções e conceitos de Paulo Freire.

Em decorrência desses parâmetros metodológicos foi possível construir a "Matriz de apropriação teórica do referencial freireano" (Quadro 3), conforme descrição a seguir:

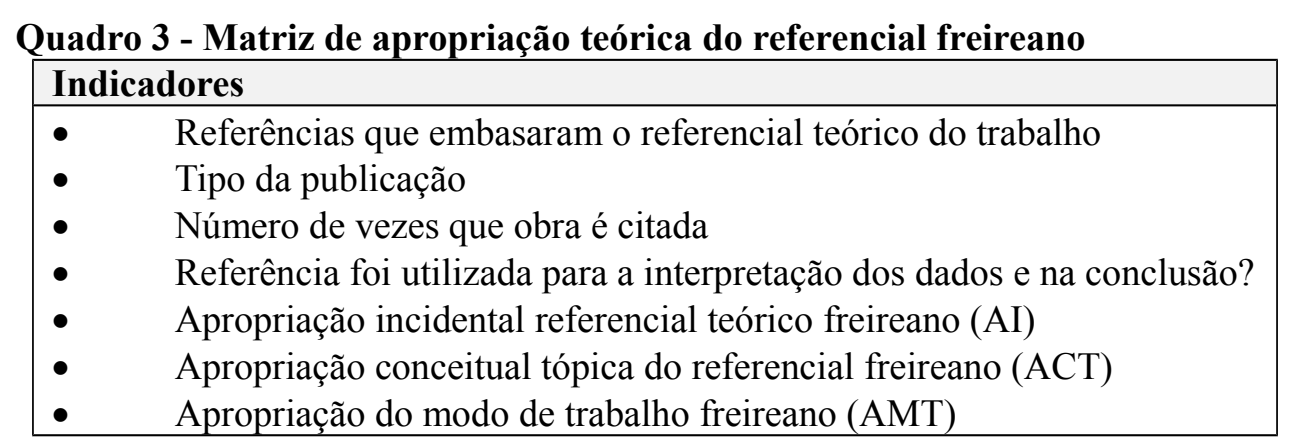

Elaboração própria

\section{Matriz paradigmática CTS}

A matriz paradigmática CTS foi composta pelos níveis teórico e epistemológico, pautados por um conjunto de visões e concepções sobre ciência e tecnologia e acontecimentos históricos que marcaram a visão CTS no ensino brasileiro.

A etapa teórica de sua construção envolveu a leitura de autores emblemáticos do Ensino de Ciências, bem como das concepções de Educação CTS e Ensino CTS, e sobre a evolução da ciência e tecnologia e acontecimentos históricos que marcaram a visão CTS no ensino brasileiro, refletidas em autores e suas respectivas obras, entre eles Ziman (1980; 1994); Aikenhead, (2000, 2003), Lemgruber (1999, 2000) e Krasilchik, (2000).

Com base na leitura e no esclarecimento dos conceitos foram identificados dois níveis: a) teórico, que agrega as concepções de Ciência, Tecnologia e Sociedade; e b) epistemológico, com as concepções: CTS, Educação CTS, Ensino CTS e Ensino de Ciências.

A partir desses níveis foram estabelecidas categorias de análise refe- 
rentes ao núcleo conceitual dos campos CTS, da Educação CTS e do Ensino de Ciências/Ensino CTS. Em decorrência desses parâmetros metodológicos foi possível construir a Matriz paradigmática CTS (Quadro 4) que agrega os níveis teórico e epistemológico.

Quadro 4 - Matriz paradigmática CTS

\begin{tabular}{|c|c|c|}
\hline Níveis & Objetivos & Referencial de análise \\
\hline \multirow{3}{*}{ Teórico } & $\begin{array}{l}\text { Concepção de } \\
\text { Ciência }\end{array}$ & $\begin{array}{l}\text { Visão crítica da ciência } \\
\text { Discussão dos limites da ciência, sua aparência objeti- } \\
\text { va e neutra } \\
\text { Atividade aberta e em construção } \\
\text { Conhecimento científico socialmente construído } \\
\text { Compreensão da natureza da ciência } \\
\text { Avaliação das aplicações da ciência } \\
\text { Avaliação dos aspectos éticos do trabalho científico }\end{array}$ \\
\hline & $\begin{array}{l}\text { Concepção de } \\
\text { Tecnologia }\end{array}$ & $\begin{array}{l}\text { Redução ao aspecto técnico } \\
\text { Uso responsável da tecnologia } \\
\text { Atividade econômica e industrial } \\
\text { Decisões pessoais envolvendo o consumo de produtos } \\
\text { tecnológicos } \\
\text { Influência sobre o comportamento humano }\end{array}$ \\
\hline & $\begin{array}{l}\text { Concepção de } \\
\text { Sociedade }\end{array}$ & $\begin{array}{l}\text { Valoriza-se a dimensão Ciência em Sociedade e Ciên- } \\
\text { cia para a Sociedade. } \\
\text { Sociedade regulamentada/direitos sociais } \\
\text { Atuação em centros comunitários, escolas, sindicatos } \\
\text { Discussão de temas sociais envolvendo interesses eco- } \\
\text { nômicos e políticos }\end{array}$ \\
\hline \multirow[t]{3}{*}{ Epistemológico } & $\begin{array}{l}\text { Concepção } \\
\text { CTS }\end{array}$ & $\begin{array}{l}\text { Vertente crítica ao desenvolvimento científico e tecno- } \\
\text { lógico } \\
\text { Incorpora dimensões sociais, políticas, econômicas e } \\
\text { culturais ao modelo de desenvolvimento } \\
\text { Incorpora preceitos da educação ambiental } \\
\text { Controvérsias científicas } \\
\text { Atividades de tomada de decisão } \\
\text { Caráter multidisciplinar } \\
\text { Disponibilidade de recursos para limitar ou ampliar o } \\
\text { progresso científico }\end{array}$ \\
\hline & $\begin{array}{l}\text { Concepção de } \\
\text { Educação } \\
\text { CTS }\end{array}$ & $\begin{array}{l}\text { Histórica - como a evolução da Ciência e a Tecnologia } \\
\text { com a Sociedade } \\
\text { Sociológica - Ciência e a Tecnologia como empreendi- } \\
\text { mentos sociais. } \\
\text { Epistemológica - natureza do conhecimento científico, } \\
\text { seus limites e a validade dos enunciados. } \\
\text { Problematizadora - grandes temas, problemas da atua- } \\
\text { lidade, contexto de relevância para o desenvolvimento } \\
\text { e aprofundamento de conceitos. }\end{array}$ \\
\hline & $\begin{array}{l}\text { Concepção de } \\
\text { Ensino de } \\
\text { CTS }\end{array}$ & $\begin{array}{l}\text { Motivação - conteúdo CTS é apenas mencionado pelo } \\
\text { professor para tornar a aula mais interessante para os } \\
\text { alunos; } \\
\text { Infusão casual - conteúdos CTS são acrescentados ou } \\
\text { infundidos em tópicos de ciência quando existem mate- } \\
\text { riais de ensino disponíveis para isso. } \\
\text { Infusão intencional - cursos de conteúdo CTS de curta } \\
\text { duração integrados ao currículo de Ciências tradicional }\end{array}$ \\
\hline
\end{tabular}




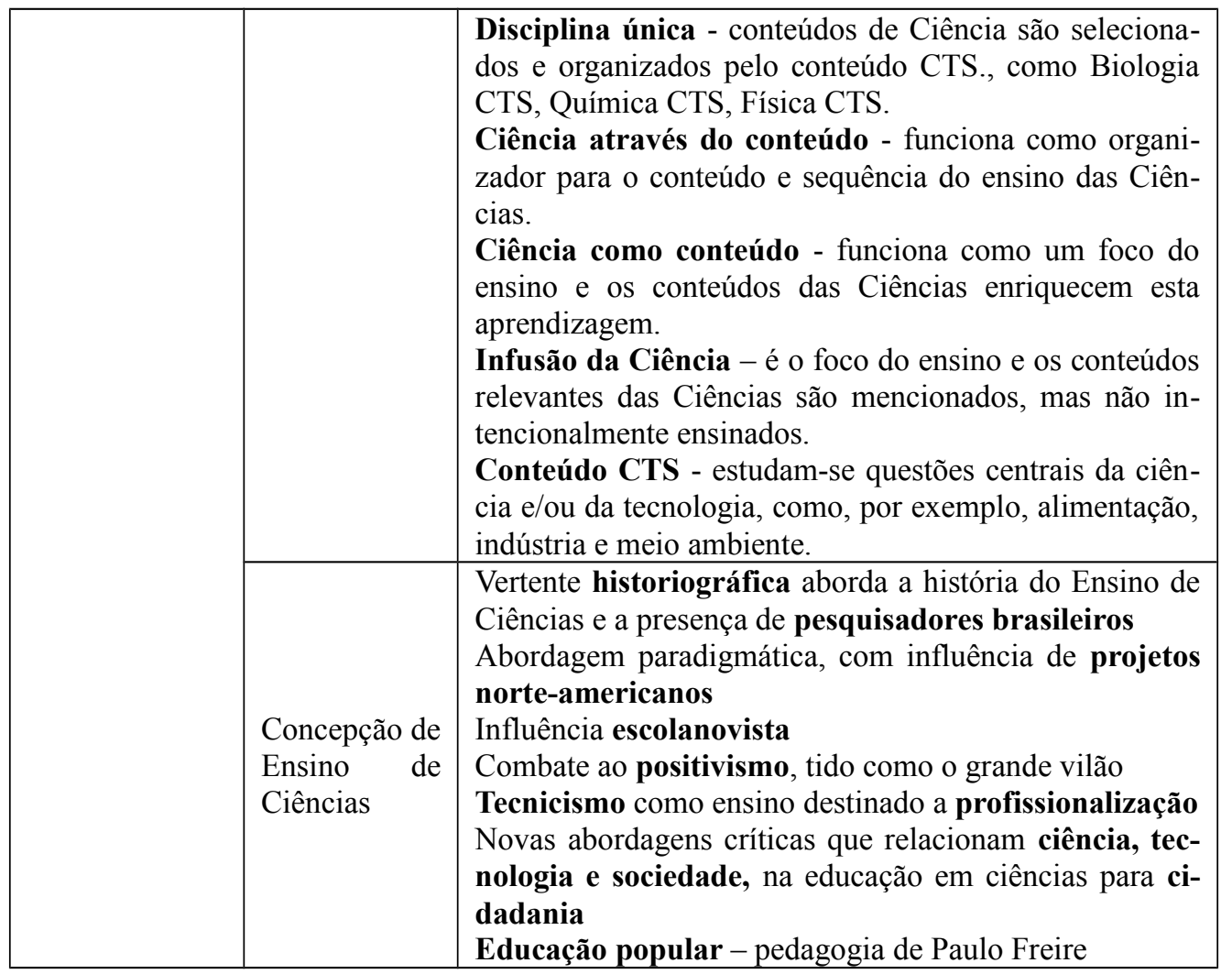

Elaboração própria

\section{Matriz de análise epistemológica do referencial freireano}

A matriz de análise epistemológica do referencial freireano agrega três níveis: o nível epistemológico, com a concepção de ciência em Paulo Freire; o nível gnosiológico, com a concepção de sujeito-objeto em Paulo Freire; e o nível ontológico com as concepções de homem, história e realidade e educação em Paulo Freire. Essa matriz foi construída tendo como referência a matriz paradigmática proposta por Sánchez Gamboa (1987) e explicitada em obras posteriores desse autor.

Para a construção da matriz de análise epistemológica, as seguintes etapas foram teóricas e metodológicas foram percorridas:

1) Leitura integral de obras de Paulo Freire (1959, 1963, 1978, 1979a, 1979b, 1983a, 1983b, 1987, 1991, 1992, 1993, 1994, 1997, 2000, 2001, $2006,2007,2011)$ e de outros autores que refletiram sobre sua obra e trajetória visando relacionar a temática da ciência e da tecnologia ao pensamento freireano.

2) Identificação de palavras e expressões de Paulo Freire presentes em 
suas obras, e que redundaram em conceitos freireanos fundamentais para identificar os pressupostos epistemológicos do seu pensamento, presentes no Dicionário Paulo Freire organizado por Streck, Redin e Zitoski (2010), cujos verbetes traduzem conceitos como "saber de experiência feito", "extensão/comunicação", "curiosidade epistemológica", "rigor/rigorosidade metódica", "sujeito/objeto".

3) Estabelecimento do núcleo conceitual freireano, considerando as categorias de nível, objetivo e referencial de análise;

4) Delineamento dos seguintes pressupostos teóricos de Paulo Freire: a) epistemológicos (A prática da extensão como um saber imposto sobre a crença popular, o saber de experiência feito, $\mathrm{O}$ ensino de conteúdos baseado na curiosidade e A crítica ao desenvolvimento científico: a pretensa neutralidade e as ideologias ocultas), gnosiológicos da abordagem (o sujeito da educação) e c) ontológicos (a concepção de homem, história e realidade);

5) Delineamento das concepções de Paulo Freire sobre ciência, sujeito-objeto, homem, história e realidade e educação;

6) Estabelecimento das categorias de análise do referencial de análise freireano.

Em decorrência desses parâmetros metodológicos foi possível construir a Matriz de análise epistemológica do referencial freireano (Quadro 5), conforme descrição a seguir:

Quadro 5 - Matriz de análise epistemológica do referencial freireano

\begin{tabular}{|c|l|l|}
\hline Níveis & Objetivos & Referencial de Análise \\
\hline \multirow{3}{*}{ Epistemológico } & $\begin{array}{l}\text { Concepção de ciência } \\
\text { em Paulo Freire }\end{array}$ & $\begin{array}{l}\text { A prática da extensão imposta sobre a crença } \\
\text { popular o saber de experiência feito; } \\
\text { O ensino dos conteúdos, o conhecimento cien- } \\
\text { tífico baseado na curiosidade epistemológi- } \\
\text { ca; } \\
\text { A neutralidade e ideologias ocultas em práti- } \\
\text { cas e linguagens. }\end{array}$ \\
\hline Gnosiológico & $\begin{array}{l}\text { Concepção de sujeito- } \\
\text { objeto em Paulo Freire }\end{array}$ & $\begin{array}{l}\text { Concepção dialógica - o homem é sujeito e } \\
\text { não objeto. } \\
\text { É protagonista, em interação com outros su- } \\
\text { jeitos. }\end{array}$ \\
\hline Ontológico & $\begin{array}{l}\text { Concepção de homem } \\
\text { em Paulo Freire }\end{array}$ & $\begin{array}{l}\text { Um ser ativo e transformador: pode mudar a } \\
\text { realidade por meio de práticas revolucioná- } \\
\text { rias; } \\
\text { Fazedor de cultura; } \\
\text { Um ser inacabado, aberto para o mundo, ca- }\end{array}$ \\
\hline
\end{tabular}




\begin{tabular}{|l|l|l|}
\hline & paz de transcender. \\
\cline { 2 - 3 } & $\begin{array}{l}\text { Concepção de história } \\
\text { e realidade em Paulo } \\
\text { Freire }\end{array}$ & $\begin{array}{l}\text { Historicidade; concepção diacrônica, univer- } \\
\text { so em construção, dinâmico, em transfor- } \\
\text { mação; } \\
\text { O homem é o sujeito de sua própria história; } \\
\text { Está inserido numa realidade concreta. }\end{array}$ \\
\cline { 2 - 3 } & $\begin{array}{l}\text { Problematizadora, não-bancária; } \\
\text { Educação popular; } \\
\text { Concepção de educa- } \\
\text { ção em Paulo Freire } \\
\text { masorável à coletividade e instituição de for- } \\
\text { Educação pelo diálogo e para o diálogo. }\end{array}$ \\
\hline
\end{tabular}

Elaboração própria

\section{Resultados da análise epistemológica do referencial freireano}

A aplicação da Matriz de Análise Epistemológica do Referencial Freireano inclui as concepções encontradas nos pressupostos epistemológicos com a concepção de ciência (saber de experiência feito; curiosidade epistemológica; neutralidade e ideologias ocultas), gnosiológicos (sujeito da educação) e ontológicos (historicidade e a concepção de homem na educação dialógica). Essa abordagem critico-dialética, por meio dos conceitos da abordagem freireana, foram aplicadas nos 13 trabalhos selecionados e os resultados são apresentados a seguir, de acordo com esses pressupostos.

\subsection{Saber de experiência feito}

$\mathrm{Na}$ prática educativa o saber de experiência feito (STRECK; REDIN; ZITKOSKI, 2010, p 365) é o ponto de partida na relação do educador com o educando, que posteriormente será superado por um saber crítico. Temática presente em seu livro Extensão ou Comunicação? (1983a), quando aborda o conhecimento imposto que ignora o saber popular. Essa dinâmica do pensamento parte da realidade concreta do educando, sendo problematizada em diferentes situações. "É preciso que discuta o significado deste achado científico; a dimensão histórica do saber, sua inserção no tempo, sua instrumentalidade. E tudo isto é tema de indagação, de diálogo" (FREIRE, 1983a, p.52).

Carletto (2009, p.85) aborda a pedagogia freireana na formação de engenheiros e salienta a oportunidade dos docentes se renovarem, reverem 
conceitos e refletirem sobre suas concepções, "em busca de uma pratica docente critico-reflexiva, de forma a formar os alunos não um deposito de conhecimentos estanques, mas sujeitos da própria aprendizagem" (CARLETTO, 2009, p.85). O saber de experiência feito é constituído pelo conhecimento empírico dos alunos, ponto de partida para o processo educativo. O conhecimento pré-científico, inserido no pensamento mágico, gradativamente será superado pelo conhecimento sistematizado pela ciência.

A abordagem dos conceitos científicos é ponto de chegada, quer da estruturação do conteúdo programático, quer da aprendizagem dos alunos, ficando o ponto de partida com os temas e as situações significativas que originam: a seleção e organização dos conteúdos a serem articulados com a estrutura do conhecimento científico e o início do processo dialógico e problematizador (CARLETTO, 2009, p. 206).

Assim como Carletto (2009), Moraes (2008) também critica a postura essencialmente tecnicista e acrítica da formação de engenheiros e futuros técnicos. Na prática imposta sobre o saber de experiência feito, Moraes (2008) alega que não parte da "posição autoritária que desconsidera e invalida a cultura primeira dos alunos. Ao contrário, procuraremos respeitá-la reconhecendo as indiscutíveis contribuições que o entendimento sobre ela pode legar ao processo educativo" (p.29).

Silva (2009, p.67) aborda Paulo Freire para discutir "as exigências do ensinar ao enfocar o respeito para com os saberes dos alunos, em especial aqueles das classes populares". Seu trabalho aborda o desenvolvimento da autonomia e propõe que haja um diálogo entre a relação desses saberes com o conteúdo ministrado, de forma a estabelecer uma "intimidade" entre os saberes curriculares fundamentais e a experiência construída socialmente".

Nas concepções epistemológicas, a ciência é vista como distante do saber dos alunos. "O ensino de Ciências, quando utiliza a lógica dos cientistas, se distancia da cultura popular, gerando desinteresse para aqueles que têm entre seu conhecimento e o aprendizado de Ciências um verdadeiro abismo a ser transposto" (SILVA, 2009, p. 140). 
Gonçalves (2008) pesquisou o universo de atores da reciclagem e identificou quatro categorias de análise, entre elas a formação de multiplicadores críticos. Essa categoria foi formada a partir da reflexão permanente dos educadores com os trabalhadores e transformada numa relação de confiança, em que os saberes dos trabalhadores com relação ao seu trabalho prático foi transmitido aos estudantes do projeto. Essa categoria se assemelha ao nível epistemológico, do saber de experiência feito frente ao saber teórico dos estudantes.

\subsection{Curiosidade epistemológica}

$\mathrm{Na}$ construção do conhecimento parte-se da curiosidade ingênua, característica do senso comum, até chegar à curiosidade epistemológica que requer o desenvolvimento da rigorosidade metódica. Na educação dialógica o rigor é essencial enquanto compromisso ético e político do educador, baseado em sua competência profissional, concebendo assim o conceito da rigorosidade metódica.

Inexiste a prática pedagógica sem conteúdo, sem um objeto de conhecimento a ser ensinado pelo educador e a ser apreendido pelo educando. A questão fundamental é a prática política oculta no conteúdo programático: o questionamento, a problematização, a abertura ao diálogo (FREIRE, 2011).

Como atividade humana, a ciência está na mediação com a sociedade e suas relações políticas, econômicas e sociais. No pensamento de Paulo Freire, a sociedade depende do desenvolvimento da ciência e da tecnologia como instrumento de crescimento e de aprendizagem. Em sua visão, "se o seu compromisso é realmente como o homem concreto, com a causa de sua humanização, de sua libertação, não posso por isso mesmo prescindir da ciência, nem da tecnologia, com as quais me vou instrumentando para melhor lutar por esta causa" (FREIRE, 1979b, p.22).

O ensino dos conteúdos, que no Ensino de Ciências trata diretamente do conhecimento científico, é baseado na curiosidade epistemológica. Situase, aqui, o saber especializado, o saber da ciência que convive com o saber intrínseco dos educandos.

No nível epistemológico, Hunsche (2010) trabalhou com categorias 
temáticas criadas a partir de elementos teóricos e dos resultados: Problemas Reais e Curiosidade Epistemológica; Aluno-Problema ou Currículo-Problema?; Formação Fragmentada; e Do "Rigor" à Flexibilidade Curricular.

No trabalho de Hunsche (2010, p.53) os estagiários descrevem o curso de Física como conteudista e distante do cotidiano dos alunos. O currículo escolar prioriza "a abordagem de conteúdos abstratos, desvinculados do mundo da vida dos educandos", fato que tem influenciado o processo de ensino-aprendizagem (HUNSCHE, 2010, p.52).

$\mathrm{Na}$ abordagem freireana, o ponto de partida para a prática da educação dialógica é considerar o saber de experiência feito, cujo objetivo é ser superado por um conhecimento científico. Com o planejamento e a utilização das temáticas, os estagiários perceberam a que a "aproximação entre o 'mundo da vida' e o 'mundo da escola' tem relação com o interesse e a participação dos alunos na aula" (HUNSCHE, 2010, p.67).

$\mathrm{O}$ interesse dos alunos possui uma ligação direta com suas vivências e deve estar previsto na organização dos conteúdos, contidos no currículo escolar. Perspectiva abarcada por Freire, que salienta: "é na realidade mediatizadora, na consciência que dela tenhamos educadores e povo, que iremos buscar o conteúdo programático da educação" (HUNSCHE, 2010, p. 57). A organização do currículo se depara com a suposta neutralidade, que esconde ideologias e favorecimentos, presente na Concepção de Ciência. O currículo deveria responder essas questões e evidenciar práticas políticas ocultas no conteúdo programático. "Para que serve a escola? Que conhecimentos ela proporciona?" (HUNSCHE, 2010, p. 62).

Neste sentido, é importante destacar que a vivência de algo diferente, como a abordagem temática, foi fundamental para que os estagiários constatassem dimensões "ocultas", ignoradas, adormecidas no contexto escolar: por exemplo, o potencial dos alunos problema, constatação somente possível pela entrada em cena de algo novo: um currículo pensado a partir de problemas/temas reais (HUNSCHE, 2010, p.89).

A curiosidade epistemológica no trabalho de Hunsche (2010, p.60) 
está relacionada com o questionamento das condições que favorecem a aprendizagem. "É possível afirmar que estagiários perceberam que existe uma relação entre tema/problemas reais e curiosidade epistemológica”. Fato comprovado na vivência em sala de aula, demonstrado quando a autora entende "que a descontextualização dos conteúdos programáticos ensinados atualmente, a desvinculação destes com o mundo vivido pelos educandos, acaba com a curiosidade epistemológica, com o querer conhecer, categoria destacada por Paulo Freire." (HUNSCHE, 2010, p.27).

Mas esse questionamento possui um fundamento, como cita Muenchen (2006) ao pesquisar a metodologia dos Três Momentos Pedagógicos. $\mathrm{Na}$ concepção epistemológica, a busca pelo conhecimento se baliza pela curiosidade, em que é considerado o saber de experiência feito, relacionado à problematização, "também apontada pelos professores, que é a de provocar a curiosidade, o querer conhecer". Dinâmica que é enfrentada pelos professores como um desafio, pois problematizar não se trata apenas de perguntas aleatórias (MUENCHEN, 2006).

Muitas perguntas não problematizaram (sic). Não despertou interesse, porque o aluno já vinha com uma bagagem, vinha com um conhecimento e eles assim, tinham outros interesses, sabe, e a gente percebe assim, a cada ano que passa, modifica também as informações, eles têm mais informações, se questionam de outras formas (MUENCHEN, 2006, p.210).

Também citada por Moraes (2008), a metodologia dos Três Momentos Pedagógicos aborda a curiosidade epistemológica destacando, "essencial para despertar a curiosidade epistemológica dos estudantes, aspecto fundamental para o sucesso de qualquer atividade educativa" (MORAES, 2008, p.184). A curiosidade aparece com tentativa de superação de um pensamento ingênuo e limitado. "É nessa tentativa de superar-se, de 'querer ser mais', que os educandos passam a desenvolver suas 'curiosidades epistemológicas"” (p. 70).

Para pesquisar o aprimoramento da docência do ensino de Ciências, Azevedo (2005) observa que a partir de um estímulo da professora, a curio- 
sidade das crianças foi despertada, gerando uma tensão criativa. Freire diz que o exercício da curiosidade convoca a imaginação, a intuição, a emoção. "Para tanto o professor necessita reconhecer nas perguntas das crianças aquelas que apresentem potencial investigativo e promovê-las de curiosidades espontâneas a curiosidades epistemológicas". (AZEVEDO, 2005, p. 157).

Todo conhecimento começa com uma pergunta, pela curiosidade, pois a curiosidade é uma pergunta. Além do mais é consenso entre ambos que o professor deve saber ensinar a perguntar, pois somente a partir de perguntas é que se deve sair em busca de respostas, e não o contrário (AZEVEDO, 2005, p.157).

Nos pressupostos epistemológicos, Cunha (2008) encontra na curiosidade a busca pelo conhecimento. "O conhecimento, pelo contrário, exige uma presença curiosa do sujeito em face do mundo. Requer sua ação transformadora sobre a realidade. Demanda uma busca constante. Implica em invenção e em reinvenção" (p. 30).

Na pesquisa de Oliveira (2005, p.31) sobre o trabalho pedagógico dos professores sobre educação ambiental, a curiosidade aparece como consequência da interação com sujeitos pedagógicos do conteúdo didático. "O interlocutor desafia e provoca os sujeitos pedagógicos, lhes arranca da passividade de meros espectadores e os induz à ação interpretativa, interrogativa". Pensamento composto com a fala freireana. "Impõe-lhes a dúvida, a necessidade de pesquisar e questionar, a aventura do conhecimento, a uma curiosidade epistemológica".

Gomes (2008) e Gonçalves (2008) citam a superação do saber ingênuo e neutro. Na concepção epistemológica, a prática docente espontânea produz um saber ingênuo, falta-lhe a rigorosidade metódica, que ele chama de curiosidade epistemológica do sujeito. O objetivo é superar o pensamento ingênuo para que se torne crítico (GOMES, 2008).

$\mathrm{Na}$ concepção epistemológica, a neutralidade e a curiosidade epistemológicas aparecem juntas. A promoção da ingenuidade para criticidade não se dá automaticamente. "Uma das tarefas da prática educativa progressista é 
o desenvolvimento da curiosidade crítica, insatisfeita, indócil. Além de um ato de conhecimento, a educação é um ato político. É por isso que não há pedagogia neutra" (GONÇALVES, 2008, p.119).

\subsection{Neutralidade e ideologias ocultas}

Na concepção epistemológica, a neutralidade da concepção de ciência aparece como superação da visão do senso comum da realidade, mediante o movimento dialético. Pensamento relacionado à Habermas, em que a ciência se cristaliza na força produtiva do capital. Nesse sentido, são atribuídas ideologias à educação ambiental, ao entender que a educação "pode assumir um papel de conservação da ordem social, reproduzindo ideologias, valores e interesses dominantes socialmente, como pode assumir um papel emancipatório, comprometido com a renovação cultural, política, e ética da sociedade" (OLIVEIRA, 2005, p.36).

A Concepção de Educação problematizada do Ensino de Ciências se depara com ideologias e conflitos ocultos em práticas e linguagens. "Entendemos a educação como uma expressão contraditória da sociedade capitalista que, por um lado, tende a manter e a reproduzir as ideologias dominantes e, por outro, é capaz de desvelar e negar essa ideologia com a sua confrontação com a realidade do educando" (CUNHA, 2008, p.62).

Cunha (2008) considera a possibilidade de inserir aspectos históricos e controversos para discutir e rever concepções sobre natureza da ciência tida como uma verdade absoluta, em que não há "espaço para dúvida, incerteza, ou controvérsia" (p. 70). O que traz à comunicação em ciências um diálogo contendo incertezas e controvérsias. "Um diálogo sobre problemas verdadeiros dos quais não se sabe a resposta e que são possíveis de se interpretar, sendo que estas interpretações podem ser conflituosas sem que haja demérito de uma das partes" (p. 33). E considera a experiência testada em seu trabalho "como possibilidade concreta de estudar a construção histórica e controversa de conceitos científicos, bem longe daquela visão pronta e acabada da ciência" (CUNHA, 2008, p. 75).

Na concepção epistemológica, a visão da ciência neutra aparece na colocação de Delizoicov, Angotti e Pernambuco (2002), a qual diz que a visão 
ingênua é superada por uma postura crítica quando os assuntos trabalhados em aula são do conhecimento dos alunos, “caso contrário é pouco provável que eles se expressem com desempenho" (STRIEDER, 2008, p.154). A pesquisadora identificou essas contradições na fala dos alunos durante sua pesquisa:

Em particular, na situação da construção da usina, foi possível identificar aspectos contraditórios que contribuíram para redimensionar possíveis críticas ao processo. Em certo sentido, os alunos, jovens, viram no alagamento de determinadas regiões e na necessidade de reassentamentos, uma possibilidade de mudança e progresso para a região, que é por eles muito almejado (STRIEDER, p.169).

Com uma posição rigorosa, Freire é contrário à ética do mercado e favorável à ética universal do ser humano. A ética é inseparável da prática educativa na maneira com que se lida com o conteúdo que é ensinado, seja nas citações de autores cuja obra é analisada.

O objetivo é superar o senso comum e atingir um conhecimento mais crítico, tarefa fundamental da educação popular progressista para compreensão da História. "Implica entendê-la e vivê-la, sobretudo vivê-la, como tempo de possibilidade, o que significa a recusa a qualquer explicação determinista, fatalista da História”. (FREIRE, 2007, p.31).

\subsection{O sujeito da educação}

De acordo com Peñalonzo (1996) uma das contribuições mais significativas de Paulo Freire é o corte epistemológico que sustenta sua filosofia social e especificamente educativa. O educando é o sujeito, e não objeto da educação.

No corte gnosiológico da educação tradicional o educador e o educando são sujeitos da educação, ambos se propõem objetos para conhecer e ambos necessitam de métodos para acercar-se do objeto cognoscível, configurando-se um desafio para seu conhecimento.

Se a vocação ontológica do homem é de ser sujeito e não objeto, só 
poderá desenvolvê-la na medida em que, refletindo sobre suas condições espaço-temporais, introduz nelas de maneira crítica.

No nível gnosiológico, a concepção de sujeito/objeto em Paulo Freire aparece no trabalho de Hunsche (2010) na figura do estagiário, futuro professor, que se coloca em interação com outros sujeitos. A autora percebeu que o professor como sujeito da própria prática pedagógica é uma tarefa difícil. "Parece que a formação do professor investigador, com objetivo de articular teoria e prática pedagógica, pesquisa e ensino, reflexão e ação didática, não tem sido um aspecto evidenciado no curso de formação destes futuros professores (HUNSCHE, 2010, p.72)".

Para Cunha (2008, p.23), a concepção de "homem sujeito" implica uma opção "entre uma educação para a domesticação, para a alienação e uma educação para a liberdade. Educação para o homem-objeto, ou uma educação para o homem-sujeito".

Na concepção gnosiológica, Santos (2002) aborda o processo de dominação quando o sujeito conquista a outra pessoa e a transforma em 'coisa', já "no processo dialógico os sujeitos encontram-se em cooperação para transformar o mundo" (SANTOS, 2002, p. 45). "É interessante notar que a professora enfatiza, em relação à questão do livro didático, o sujeito da pergunta NÓS, o que tem por objetivo fazer com que o aluno apresente propostas de ações que possam ser feitas por ele, enquanto simples consumidor".

A educação para Freire, da qual compartilhamos, é aquela para o homem-sujeito e, portanto, não poderia ser diferente que a educação científica que pretendemos é aquela para o homem-sujeito. Mas qual seria esse homem-sujeito no ensino de ciências? (...) E nada mais óbvio que a educação científica para o homem-sujeito seja aquela problematizadora da situação humana no mundo com o mundo com que não se faz sem diálogo (CUNHA, 2008, p.33).

Moraes (2008) indica que o homem é sujeito da ação educativa, podendo influir também no conteúdo. Apropriando-se de Delizoicov (1983, p.63), "é necessário considerar o educando como sujeito da ação educativa, e não como objeto passivo desta, o que implica que a sua participação no 
processo deve ocorrer em todos os níveis, inclusive na definição do conteúdo programático". A concepção de homem aparece como um ser capaz de transcender.

Ao serem confrontados por situações-limite, os estudantes conseguiram superar seus horizontes cognitivos, vislumbrando, assim, o inédito-viável. Prova disto são suas manifestas declarações que exaltam a promoção de suas criticidades, do reconhecimento de suas capacidades de intervir nas questões públicas, nos processos decisórios da sociedade (MORAES, 2008, p.182).

A concepção de sujeito/objeto na pedagogia bancária mantém "o modelo originário do trabalho humano (sujeito versus objeto, homem versus natureza) no âmbito do trabalho pedagógico (sujeito versus sujeito), ou seja, manter a relação sujeito versus objeto como modelo do trabalho pedagógico". Na posição bancária o educador "assume a postura ativa de noticiador, informador ou transmissor de conteúdos, de sujeito pedagógico; o educando assume a uma posição oposta, passiva, de receptor de conteúdos, de objeto pedagogizável" (OLIVEIRA, 2005, p.29).

Strieder (2008) estabelece uma reflexão em que aluno, professor e conhecimento passam a desempenhar outro papel. Ou seja, o aluno deve passar a ser visto como "sujeito do conhecimento" e, para tanto, é importante encontrar mecanismos que façam com que ele se envolva no processo de ensino aprendizagem (STRIEDER, 2008, p.163). No caso, as professoras permaneceram apenas como expectadoras e outras participaram ativamente, tomando iniciativas e sugerindo encaminhamentos. Strieder (2008, p.142) entende que a ausência de autonomia por parte das professoras, quanto o envolvimento diferenciado, esteja associada a três aspectos: (i) à compreensão que ela possui sobre o papel do professor; (ii) à relação que possui com a situação, no caso, com a usina; (iii) sua característica pessoal.

No trabalho de Gonçalves (2008, p.134) os trabalhadores se tornaram sujeitos de suas práticas sociais. "A oportunidade de trabalhadores imersos em fragilidades sociais de práticas educativas populares progressistas fortalece a constituição desses atores se tornarem dirigentes, com originalidade 
inventiva, portadores de senso de transformação". De forma a comunicar os associados seu direito de participarem de processos educativos e demonstrar que são capazes de aprender e ensinar.

Os protagonistas desses processos educativos, os professores, os estudantes, e os associados desenvolveram muito mais do que ações pontuais. Essas práticas constituíram um processo de formação fundamentado em reflexões sobre premissas pedagógicas freireanas de contribuir na construção de conhecimentos atrelados a situação da realidade (GONÇALVES, 2008, p.135).

Oliveira (2005, p.86) aponta que há professores que possuem uma visão de conhecimento "interativa entre os sujeitos (sujeito versus sujeito), incorporando, dessa forma, o método dialógico de ensino". Concepção "um pouco tímida em relação à sua abrangência no trabalho pedagógico dos professores", sendo que a maioria não se reconhece como sujeito do processo educativo.

Esses professores entendem que a participação somente se dá diretamente no processo de decisão. E, portanto, não se sentem sujeitos do processo e, isto, consequentemente, acaba gerando passividade, indiferença, fixidez em relação à socialização dos conteúdos sistematizados na proposta (OLIVEIRA, 2005, p.87).

\subsection{Historicidade e a concepção de homem na educação dialógica}

Freire enfatiza em sua concepção de mundo o aspecto predominantemente objetivo em função do momento histórico vivido por ele, pela especificidade da realidade brasileira daquele momento, onde as classes populares marginalizadas dos benefícios da nova sociedade industrial lutavam pelo direito de garantia de satisfação das suas necessidades básicas (alimento, saúde, educação, habitação etc.) (BRENNAND, 2013, p. 2).

Os fenômenos educativos possuem uma natureza social e histórica e assim a investigação em educação necessariamente deve ser trabalhada com a historicidade. Para Paulo Freire o indivíduo é colocado numa perspectiva histórica. Quando a leitura do mundo precede à leitura da palavra, se reco- 
nhece a historicidade do saber e o caráter histórico da realidade. "Mas, histórico como nós, o nosso conhecimento no mundo tem historicidade" (FREIRE, 2001, p.30).

Na visão de Freire a história de uma pessoa é composta de suas vivências e memórias. Isso remete à continuidade histórica, ao saber de historicidade, pois "Mulheres e homens, seres histórico-sociais, nos tornamos capazes de comparar, de valorar, de intervir, de escolher, de decidir, de romper, por tudo isso, nos fizemos seres éticos" (FREIRE, 2001, p.34).

De acordo com Streck, Redin e Zitkoski (2010), nos livros de Paulo Freire a historicidade possui uma relação direta com o saber e a curiosidade epistemológica. "Ser histórico-sócio-cultural, fazendo-se e refazendo-se na história que faz, o ser humano é naturalmente curioso, mas a sua curiosidade histórica, tal qual ele, opera em níveis diferentes que produzem achados também diferentes" (FREIRE, 2000, p. 103).

O conceito de autonomia no trabalho de Silva (2009) aborda a problemática do homem como sujeito da sua própria história. "A condição sóciohistórica de um povo ou pessoa que tenha se libertado, se emancipado das opressões que restringem ou anulam sua liberdade de determinação. Conquistar a própria autonomia implica, para Freire, em libertação das estruturas opressoras" (SILVA, 2009, p.43).

A autonomia é agir, realizar, refletir, dialogar que vai além da liberdade de pensar por si, além da capacidade de guiar-se por princípios que concordem com a própria razão, o que exige um homem consciente e ativo (SILVA, 2009, p.44).

Na concepção ontológica, Cunha (2008) trabalha com o conceito de humanização e desumanização, numa situação de opressão concreta de uma realidade histórica. Defende uma transformação na educação científica que apenas repete o conhecimento herdado, em vez de recriá-lo.

Como pode o ensino de ciências ser desprovido de história se o que caracteriza o homem também é sua temporalidade e sua transcendência? Ou seja, como pode o ensino de ciências humanizar se com o que ele se preocupa é em contar a história assim como ela não 
foi? A ciência que é feita pelos cientistas não é a mesma que se herda na educação científica. O legado científico deixado pela humanidade deixou de ser herdado na educação científica há tempos. Esta educação científica nada mais é que o produto pronto e acabado, por isto, desumanizante. A educação científica é desumanizante porque, ao invés de herdar, criar e recriar o legado científico, o estudante recebe um produto pronto acabado há séculos, formatado há décadas e repetido há anos. A este estudante, por sua vez, só cabe receber, quanto mais, melhor será. (CUNHA, 2008, p. 32).

O homem de Paulo Freire é um ser social e histórico que faz e transforma. "Ele indica a solidariedade como compromisso histórico de forma de luta de homens e mulheres para instaurar a ética universal do ser humano" (GOMES, 2008, p.46). Essa luta está configurada na sociedade concreta, desafiado pela realidade objetiva. "Cabe a ele, como um ser no mundo e com o mundo, captar a realidade de forma crítica, conhecê-la e transformá-la. Num pensar dialético, ação e mundo, mundo e ação estão intimamente solidários".

No nível ontológico, a Concepção de Realidade é diacrônica. A fala dos estagiários aponta que um trabalho na perspectiva da abordagem temática entende a construção do conhecimento como algo dinâmico, em transformação. "Frente a um currículo mais flexível, pautado pela abordagem temática, os alunos, acima de tudo os ditos 'alunos-problema', passam a participar de forma mais ativa em sala de aula, empenhando-se para a construção do conhecimento coletivamente" (HUNSCHE, 2010, p. 68).

A concepção de homem é de um ser inacabado, em construção, inserido numa realidade diacrônica. Azevedo (2005) se apropria de Freire quando distingue a predisposição à busca, e à mudança, denominadas fundantes. "Somos seres inconclusos, inacabados, interminados perante o mundo, pois a consciência de si como ser inacabado necessariamente inscrever o ser consciente de sua inconclusão num permanente movimento de busca (AZEVEDO, 2005, p.154)".

$\mathrm{Na}$ concepção ontológica freireana o ser humano é inacabado, “está em constante mudança para conhecer, transformar e assim integrar a socie- 
dade" "Diante disso, entendemos que o objetivo do trabalho pedagógico é contribuir para a construção e reconstrução do conhecimento" (OLIVEIRA, 2005, p.31).

A concepção do homem como ser inacabado e em transformação aparece de forma inversa no trabalho na visão do professor como alguém que precisa, acima de tudo, saber o conteúdo e tem como transmitir seus conhecimentos aos alunos (STRIEDER, 2008).

Dessa forma, a dinâmica por nós sugerida, causava certo desconforto às professoras, pois, as dúvidas e perguntas eram maiores que as respostas que tínhamos. Seja porque não havia respostas, já que era uma questão aberta, seja porque não tínhamos informações suficientes a respeito (STRIEDER, 2008, p.142).

\subsection{Educação dialógica}

Na concepção de educação, Moraes (2008) utiliza a problematização como guia da pesquisa para estimular os discentes na forma com que se relacionam com as discussões propostas no processo educativo, combinação dos estudos educacionais CTS com a metodologia freireana para formar cidadãos-técnicos.

Sim, a inserção de uma disciplina que promova a discussão das inter-relações entre ciência, tecnologia e sociedade, nos currículos dos cursos de educação tecnológica, pode auxiliar no processo formativo de técnicos socialmente críticos, capazes de exercer sua cidadania com plenitude (MORAES, 2008, p.182).

Quanto à problematização, foi observada a ausência de discussão e questionamento no trabalho de Strieder (2008, p.154). A autora afirma que para o desenvolvimento de uma postura crítica, "é imprescindível que o processo seja dialógico, ou seja, que haja uma reflexão em conjunto, educador e educandos voltados para o mesmo problema, o que envolve respeito de ambas as partes e não imposição de ideias de um sobre os outros". Numa concepção de realidade diacrônica, o trabalho buscou transformar, numa ação concreta de confecção e distribuição de panfletos informativos sobre a usi- 
na. Destaca que, em virtude da ausência de uma cultura de participação, a proposta de "transformar" o conhecimento construído pelos alunos em prol da formação da comunidade partiu do pesquisador/educador".

$\mathrm{Na}$ concepção de educação em Paulo Freire, Hunsche (2010) afirma que a educação dialógica foi percebida pelos estagiários quando destacaram a que a "interação e o diálogo entre educandos e educadores propiciam uma maior compreensão dos conceitos científicos". De modo a perceberem que o conhecimento foi construído em conjunto com a participação dos alunos. Estes apontamentos não estão na perspectiva de uma escola que considera como aluno ideal aquele que é silencioso, passivo, que ouve a fala do professor como única e verdadeira, aspectos discutidos na categoria seguinte, 'aluno-problema ou currículo-problema? (HUNSCHE, 2010, p.56).

Muenchen (2006) se apropria de Paulo Freire compondo a concepção de educação, na qual a problematização é o alicerce para a prática dialógica. A prática problematizadora de Paulo Freire implica no diálogo "em torno de situações significativas para os alunos e que envolvem contradições, e dialogar não é perder tempo, pois, a partir do diálogo que problematiza, estamos propiciando aos educandos tornarem-se sujeitos do processo" (MUENCHEN, 2006, p.206).

Trabalhada juntamente com o diálogo, a problematização identifica contradições. "Em conexão com diferentes áreas do saber, poderão ser trabalhadas em favor de soluções envolvendo questões técnico-científicas, éticas, sociais, históricas, culturais e ambientais” (p.203). Na educação problematizadora “(...) os educandos vão se transformando em sujeitos de construção e reconstrução do saber ensinado, ao lado do educador, igualmente sujeito do processo (CARLETTO, 2009, p.204)”.

O diálogo é realizado com os conhecimentos que professor e aluno, ambos sujeitos da educação, detêm sobre o tema de estudo. "Requer docentes capazes de promover o diálogo entre conhecimentos, de maneira a propiciar a problematização e a reflexão crítica". Mas Carletto (2009) conclui que a maioria dos professores ainda não está preparada, configurando um desafio a ser enfrentado.

Strieder (2008) percebe "que a escola atual está distante de ser a esco- 
la idealizada por Freire". Na concepção ontológica de educação, quanto à problematização, Strieder (2008, p.130) destaca que não faz parte da cultura da escola atual buscar soluções para problemas da comunidade. "Em virtude da ausência de uma cultura de participação, a proposta de 'transformar' o conhecimento construído pelos alunos em prol da comunidade ainda deve partir do educador". Mas é preciso estimular ações "pois passar a ter iniciativas demanda um longo processo".

Silva (2009) faz críticas à metodologia da escola que segue o padrão bancário de educação, "que não admite a diversidade entre os alunos, replica as condições instauradas, desenvolve apenas aqueles que estão enquadrados no sistema, impedindo a transformação" (SILVA, 2009, p. 137). O processo de problematização está próximo ao do diálogo, propondo a busca pelo conhecimento. "O educando se confronta com situações de seu cotidiano, que desestabiliza o seu conhecimento anterior e cria a necessidade de um novo conhecimento. Para ocorrer é necessário que haja diálogo entre quem ensina e quem aprende" (SILVA, 2009, p. 139).

Coerente com a proposta de Paulo Freire, o letramento científico tem por objetivo problematizar temas sociais de modo a assegurar um comprometimento social dos educandos, uma vez que

Essa mediatização ocorre por meio de uma educação problematizadora, de caráter reflexivo, de desvelamento da realidade, na qual o diálogo começaria a partir da reflexão das contradições básicas da situação existencial. É nessa reflexão que o diálogo permite a educação para a prática da liberdade (SANTOS, 2002, p.47).

A concepção de educação está centrada na pedagogia humanizadora, relação dialógica permanente e intencional e baseada em valores e virtudes, como a humildade, a curiosidade, a coragem, a capacidade de decidir e de colocar limites, além, do compromisso e objetivos a que se propõe (GOMES, 2008, p. 28).

A partir da formação de professores de ciências mais solidários acredita que como o conhecimento biológico, posturas éticas, e engajamento político, um início de interlocuções mais amplas sobre 
valores, com uma maior participação social, com contribuições importantes na transformação social planetária concomitantemente ao conhecimento científico, caberia, a esses professores, propor maneiras de vivenciar valores em atitudes visivelmente solidárias (GOMES, 2008, p. 107).

Na concepção ontológica, Oliveira (2005, p.79) conceitua a educação ambiental como bancária que favorece uma educação conservadora. "São objetivos como: formar o aluno... levar o aluno... objetivos desse tipo indicam autoridade de um ser sobre outro ser. Uma concepção autoritária de trabalho, uma concepção bancária de educação". Entretanto, a autora acredita que o trabalho pedagógico possa acontecer numa construção histórica e coletiva "para a tomada de consciência do movimento histórico-social do ser humano." (OLIVEIRA, 2005, p.32). "Uma atividade dirigida conscientemente e comunicativamente dialogada e reflexiva pelos sujeitos envolvidos no processo de construção e reconstrução do conhecimento".

Quanto à concepção de educação problematizadora, esse processo de comunicação instaurou as ações educativas e de pesquisa, movimentou a interdisciplinaridade, permitiu a dialogicidade e criou laços de proximidade entre recicladores que se organizaram numa associação que tem como base a economia solidária. As práticas educativas construídas na pesquisa de Gonçalves (2008) contribuíram para uma "leitura crítica do mundo, para autonomia, a dignidade, a superação da dependência e emancipação e formação da cidadania comprometida com equilíbrio social" (GONÇALVES, 2008, p.133).

\section{Considerações Finais}

O Ensino de Ciências e a Educação CTS utilizam a pedagogia de Paulo Freire para suprir uma lacuna do Ensino de Ciências, configurando uma educação científica dialógica.

De natureza bancária, a discussão do desenvolvimento científico e tecnológico, seus malefícios e benefícios, a importância do pensamento científico na formação do aluno são temas tratados pela literatura nacional, inspirados em programas educacionais da Europa e Estados Unidos. Entre- 
tanto essa perspectiva possui um viés linear e limitado, e esbarra muitas vezes no desinteresse nos alunos e na falta de estímulo, de curiosidade e de desafios.

A utilização da matriz de análise epistemológica do referencial freireano comprovou que os trabalhos analisados se apropriam das concepções freireanas indicando uma abordagem critico-dialética. Numa perspectiva dialógica, a concepção de ciência se inseriu em categorias como a curiosidade epistemológica, na investigação do conhecimento com o saber de experiência feito, contextualizado em sua historicidade, transformando o aluno no sujeito de sua aprendizagem. Desta forma o ensino científico é colocado num patamar epistemológico, problematizado como um saber reflexivo, dinâmico, em transformação e coerente com sua realidade.

\section{Referências}

AIKENHEAD, Glen. STS in Canada: From policy to student evaluation. In: KUMAR, D. D.; CHUBIN, D. (Eds.). Science, technology, and society: a sourcebook on research and practice. New York: KluwerAcademic/PlenumPublishers, 2000. p. 49-89. Disponível em:

<http://www.usask.ca/education/people/aikenhead/stsincan.htm> Acesso: 21 maio 2013.

AIKENHEAD, Glen. STS education: a rose by any other name. In: CROSS, R. (Ed.): A vision for Science Education: responding to the work of Peter J. Fensham. New York: Routledge Falmer, p. 59-75, 2003.

BRENNAND, Edna Gusmão de Goés. Buscando em Paulo Freire as concepções de individuo e mundo. In: UFPB, Biblioteca Digital Paulo Freire, 2013. Disponível em:

http://www.paulofreire.ce.ufpb.br/paulofreire/Files/revista/Buscando_em_Pa ulo_Freire_as_concepcoes_de_individuo_e_mundo.pdf. Acesso em 8fev 2013.

CATANI, Afrânio Mendes; CATANI, Denice Bárbara; PEREIRA, Gilson R. de M. As apropriações da obra de Pierre Bourdieu no campo educacional brasileiro, através de periódicos da área. Revista Brasileira de Educação, Maio/Jun/Jul/Ago 2001 n. 17, p.63-85.

DELIZOICOV, Delizoicov; ANGOTTI, José André; PERNAMBUCO, Marta Maria Ensino de Ciências: fundamentos e métodos. São Paulo: Cortez, 2011.

FREIRE, Paulo. Educação e atualidade brasileira. Recife: Universidade Federal do Recife, 139p. (tese de concurso público para a cadeira de História e Filosofia da Educação de Belas Artes de Pernambuco), 1959. 
FREIRE, Paulo. Alfabetização e conscientização. Porto Alegre: Ed. Emma, 1963.

FREIRE, Paulo. Cartas à Guiné-Bissau: registros de uma experiência em processo. Rio de Janeiro: Paz e Terra, 1978.

FREIRE, Paulo. Educação como prática da liberdade. Rio de Janeiro: Paz e Terra, 1979a.

FREIRE, Paulo. Educação e mudança. Rio de Janeiro: Paz e Terra, 1979b.

FREIRE, Paulo. Extensão ou comunicação?. Rio de Janeiro: Paz e Terra, 1983a.

FREIRE, Paulo. Pedagogia do oprimido. Rio de Janeiro: Paz e Terra, 1983b.

FREIRE, Paulo. A Importância do Ato de Ler: em três artigos que se completam. São Paulo: Cortez Editora \& Autores Associados, 1987.

FREIRE, Paulo. A educaşão na cidade. São Paulo: Cortez, 1991.

FREIRE, Paulo. Pedagogia da esperança: um reencontro com a Pedagogia do oprimido. Rio de Janeiro: Paz e Terra, 1992.

FREIRE, Paulo. Professora sim, tia não: cartas a quem ousa ensinar. São Paulo: Olho d'água, 1993.

FREIRE, Paulo. Cartas a Cristina. São Paulo: Paz e Terra, 1994.

FREIRE, Paulo. Globalização, ética e solidariedade. In: RESENDE, P.;

DOWBOR, L.; IANNI, O. Desafios da globalização. Petrópolis: Vozes, 1997.

FREIRE, Paulo. Pedagogia da Indignação: cartas pedagógicas e outros escritos. São Paulo: editora UNESP, 2000.

FREIRE, Paulo. À sombra desta mangueira. São Paulo: Olho d'água, 2001.

FREIRE, Paulo. Ação cultural para a liberdade e outros escritos. Tradução de Claudia Schilling, Buenos Aires: Tierra Nueva, 2006.

FREIRE, Paulo. Politica e educação: ensaios. São Paulo: Cortez, 2007.

FREIRE, Paulo. Pedagogia da Autonomia: saberes necessários à prática educativa. Rio de Janeiro: Paz e Terra, 2011.

FREIRE, Paulo; FREIRE; Ana Maria A. (org.). Pedagogia dos sonhos possiveis. São Paulo: Editora UNESP, 2001.

FERNANDES; Carolina dos Santos; MARQUES, Carlos Alberto. Ciência, tecnologia e sociedade e a perspectiva freireana de educação: possíveis convergências. In: VII Enpec. Encontro Nacional de Pesquisadores em Educação em 
Ciências. Florianópolis - SC, 2009. Anais... Florianópolis: VII Enpec, 2009.

GOHN, Maria da Glória. Paulo Freire e a formação de sujeitos sociopolíticos. In: IV Forum Internacional Paulo Freire. Anais... IV Forum P. Freire. Porto: Univ. do Porto/Inst. Paulo Freire, 2004.

HAYASHI, Maria Cristina Piumbato Innocentini.; FERREIRA JUNIOR, Amarilio; BITTAR, Marisa.; HAYASHI, Carlos Roberto Massao.; SILVA, Márcia Regina da. História da educação brasileira: a produção científica na biblioteca eletrônica SCIELO. Educaşão \& Sociedade, v. 29, p. 181-211, 2008.

KRASILCHIK, Míriam. Reformas e realidade: o caso do ensino das ciências. São Paulo Perspec., São Paulo, v. 14, n. 1, mar. 2000. Acesso em: 7 abr. 2013.

HAYASHI, Maria Cristina Piumbato Innocentini; FERREIRA JUNIOR, Amarilio; BITTAR, Marisa; HAYASHI, Carlos Roberto Massao; SILVA, Márcia Regina da. História da educação brasileira: a produção científica na biblioteca eletrônica Scielo. Educaşão \& Sociedade, v. 29, p. 181-211, 2008.

LEMGRUBER, Márcio Silveira. A Educação em Ciências Físicas e Biológicas a Partir das Teses e Dissertacõos (1981 a 1995): uma história de sua história. Tese (Doutorado em Educação) Universidade Federal do Rio de Janeiro, UFRJ, 1999.

LEMGRUBER, Márcio Silveira. Os educadores em ciências e suas percepções da história do ensino médio e fundamental de ciências físicas e biológicas, a partir das teses e dissertações (1981 a 1995).In: 23a. Reunião Anual da ANPEd - Associação Nacional de Pós-Graduação e Pesquisa em Educação., 2000, Caxambu - MG. Anais...23a. Reunião Anual da ANPEd, 2000.

PEÑALONZO, Jacinto Ordóñez. O corte epistemológico de Paulo Freire. In: GADOTTI, M (org). Paulo Freire: uma biobibliografia. Cortez Editora, 1996, p. 573-576.

SÁNCHEZ GAMBOA, Silvio. Epistemologia da Pesquisa em Educação. Campinas: UNICAMP, 1987. (Tese de Doutorado).

SÁNCHEZ GAMBOA, Silvio. Pesquisa em Educação: métodos e epistemologias. Chapecó: Argos, 2012.

SILVA, Márcia Regina da; HAYASHI, Maria Cristina Piumbato Innocentini; HAYASHI, Carlos Roberto Massao. Análise bibliométrica e cientométrica: desafios aos especialistas que atuam no campo. InCID: Revista de Ciência da Informação e Documentação, v. 2, p. 110-129, 2011.

STRECK, Danilo R; REDIN, Euclides; ZITKOSKI, Jaime José. Dicionário Paulo Freire. Belo Horizonte: Autêntica Editora: 2010.

ZAUITH, Gabriela; OGATA, Márcia Niituma; HAYASHI, Maria Cristina Piumbato Innocentini. Panorama da produção científica em educação CTS no Brasil. In: VIII Jornadas Latinoamericanas de Estudios Sociales de la Ciencia y 
la Tecnología, 2010, Buenos Aires. Anais... VIII Jornadas Latinoamericanas de Estudios Sociales de la Ciencia y la Tecnología, 2010.

ZAUITH, Gabriela; OGATA, Márcia Niituma; HAYASHI, Maria Cristina Piumbato Innocentini. Um breve panorama sobre a Educação CTS no Brasil. In: HOFFMANN, W. A. M. (Org.). Ciência, tecnologia e sociedade: desafios da construção do conhecimento. São Carlos: Edufscar, 2011. p. 21-38.

ZAUITH, Gabriela; HAYASHI, Maria Cristina Piumbato Innocentini. A perspectiva freireana e o movimento CTS: um recorte a partir do Google Acadêmico. In: Simpósio Nacional de Tecnologia e Sociedade, 4, 2011, Anais...., Curitiba, 2011a, p.1-11.

ZAUITH, Gabriela; HAYASHI, Maria Cristina Piumbato Innocentini. A apropriação do referencial teórico de Paulo Freire nos estudos sobre educação CTS. Revista Brasileira de Ciência, Tecnologia e Sociedade, v.2, n.1, p. 278-292, jan./jun. 2011b.

ZAUITH, Gabriela; HAYASHI, Maria Cristina Piumbato Innocentini. A influência de Paulo Freire no Ensino de Ciências e na Educação CTS: uma análise bibliométrica. Revista HISTEDBR On-line, v. 13, p. 267-293, 2013.

ZIMAN, John. Teaching and learning about science and society. Cambridge: Cambridge University Press, 1980.

ZIMAN, John. The rationale for STS is in the approach. In J. Solomon \& G. Aikenhead (Eds.), STS education: International perspectives on reform. New York: Teachers College Press, 1994. p. 21-31.

\section{Teses e Dissertações Analisadas}

AZEVEDO, Maria Nizete. Pesquisa-ação e atividades investigativas na aprendizagem da docência em ciências. Dissertação (Mestrado em Educação). Universidade de São Paulo. São Paulo: USP, 2008.

CARLETTO, Maria Regina. Avaliação De Impacto Tecnologico: Alternativas E Desafios Para A Educação Crítica Em Engenharia. Tese (Doutorado em Educação Científica e Tecnológica). Universidade Federal de Santa Catarina. Santa Catarina: UFSC, 2009.

CUNHA, Ailson V. Considerações sobre os aspectos cinemáticos e dinâmicos do movimento. Dissertação (Mestrado em Educação para a Ciência). Universidade Estadual Paulista Júlio de Mesquita Filho. Bauru: UNESP, 2008.

GEHLEN, Gehlen Tormohlen. A função do problema no processo ensino-aprendizagem de ciências: contribuições de Freire e Vygotsky. Tese (Doutorado em Educação Científica e Tecnológica). Florianópolis: UFSC, 2009.

GOMES, Carlos. A solidariedade como um dos valores norteadores da formação do professor de ciências e de biologia. Mestrado (Dissertação em Educação - Currículo). 
Pontifícia Universidade Católica de São Paulo. São Paulo: PUC-SP, 2008.

GONÇALVES, Fernando José Fernandes. Ações educativas participativas para os atores da reciclagem: Uma Abordagem CTS. Dissertação (Mestrado em Educação Científica e Tecnológica). Universidade Federal de Santa Catarina. Santa Catarina: UFSC, 2008.

HUNCHE, Sandra. Professor "fazedor" de curriculos: desafios no estágio curricular supervisionado em Ensino de Física. Dissertação (Mestrado em Educação). Universidade Federal de Santa Maria. Santa Maria: UFSM, 2010.

MORAES, Gustavo Henrique. Educação tecnológica, formação humanista: Uma experiência CTS no CEFET-SC. Dissertação. (Mestrado em Educação Científica e Tecnológica). Universidade Federal de Santa Catarina. Santa Catarina: UFSC, 2008.

MUENCHEN, Cristiane. A disseminação dos Três Momentos Pedagógicos: Um estudo sobre práticas docentes na região de Santa Maria/RS. Tese (Doutorado em Educação Científica e Tecnológica) Universidade Federal de Santa Catarina. Santa Catarina: UFSC, 2010.

OLIVEIRA, Marinalva Luiz de. O trabalho pedagógico dos professores do ensino fundamental no ciclo II sobre educação ambiental Recife - PE. Dissertação (Mestrado em Ensino de Ciências). Recife: UFRPE, 2005.

SANTOS, Wildson Luiz. Aspectos sociocientificos em aulas de Química. Tese (Doutorado em Educação). Universidade Federal de Belo Horizonte. Belo Horizonte: UFMG/FaE, 2002.

SILVA, Walessandra Araújo. Possibilidades de desenvolvimento da autonomia nas aulas de física utilizando o movimento Ciências, Tecnologia e Sociedade. Dissertação (Mestrado em Educação). Centro Universitário Salesiano de São Paulo. São Paulo: UNISAL - SP, 2009.

STRIEDER, Roseline Beatriz. Abordagem CTS e ensino médio: espaços de articulação Dissertação (Mestrado em Ensino de Ciências). Instituto de Física, Departamento de Física Experimental. São Paulo: USP, 2008. 